に転移点に於ける透電率の变化量 $\Delta \varepsilon^{\prime}$ はらて中の水分量 の増加と其に急激に大きくなり，その变化量は水分の多 い所では高分子の配向のみから期待される量よりも遥か に大きい值となるからである。然し，この場合水の双極 子の寄与を積極的に考えればならない理由はそれ程明ら かではなく，令後の研究に待つるのである。

総

括

ゼラチンゲルの透電率及び瓦尊度をゲルの濃度，温度 及び周波数を急えて浿定した処，弾性率の湜度变化及び
ディラトメトリーによって得られた二次転移点と殆んど 同一温度 (少し高温) に於いて，これに対応する特異な 变化を認めた。この透電的転移点心水分量と共に始め急 激に, 後 $60 \%$ むたりからやや緩やかに低下し, 普通の 濃度のゲルでは常温以下になる。この温屋に於ける透電 率及び伝導度の变化には，高分子七グメントの双極子の 電場に対する配向運動が関与していると考えられる。

終りに臨み終始御指導をた末わった川北公夫教授及び 有益なる御教示, 御討議をいただいた京大化学研究所小 泉淔一氏に対し厚く謝意を表する。

(東京工業大学然料科学研究所，㷊京都目黒区（昭和 28 作4月 28 日受理)

\title{
ラマン線の强度と分子楎造（第7 報）
}

\section{强度の和と分子構造との関绿 II}

\author{
(强度測定值による検討)
}

吉野 常 夫

分子 1 のる一の㟤素原子に関する分子内座標の種 類互び数が, 分子 2 のつの炭素原子に関する分子内座 標の種類及び数と同しでるよらな対応が，分子 1 と 2 のすべてい宸素原子について一対一に存在するとさし れを条件Aをするう，分極率理論から次の関保か導か れることを剖報りにのへた。

$$
J_{1} \equiv \sum_{a} I_{1 a} \kappa_{1 a} / \omega_{1 a} \doteqdot \sum_{a} I_{2 a} \kappa_{2 a} / \omega_{2 a} \equiv J_{2} \quad(1)^{*}
$$

ここて $\omega_{1 a}$ は分子 1 の $a$ 番目の基準振動の振動数， $I_{1 a}$ はそのラマン楾の強度, $\kappa_{a}=\left\{1-\exp \left(h \omega_{a} / k T\right)\right\}, \sum_{a}$ は 分子のすべてのラマン線について加え岕わせることをあ ら和す。但し(1)は，分子内再標 $r$ D变化长よる分通率 aの変化 $\partial \boldsymbol{\alpha} / \partial r$ が，条件Aをみたす分子 1 と2とで対

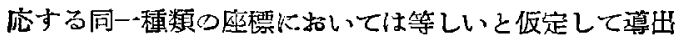

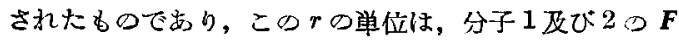
行列のすべての対角項が 1 となるようにとってある(第 5 垠参照。

(I)は $\boldsymbol{F}$ 行列の交羿項がテトラメチ儿メタンよりる小 さい(島内の力の定数による。前報参照)ことを条件と

1)吉乐。就 74、712 (1953).

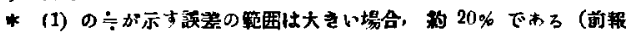
至照.

2) 吉野, 本就 74, 388 (1953).
して尊出された。この条件は特殊の場合を除いた殆んど すへての分子に括いてみたされているから，通常(1)は 適用てきると考えられる。従って，種々の構造の分子の $J$ を比較することによって，Jと分子構造との関係を求 めることが意味を持ち，分子棈造の相違によるJ及び $\partial \alpha / \partial r$ の美異を調べることが可能となる。

前報にのべたように（1)を適用できるような分子に

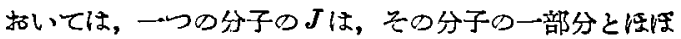
同等な分子の $J$ 和であらわされるとのことを以下に 咕いて(2)と略記する)。従っと, 分子量の異なる分子 間で Jを比輘することができ，これらの分子構造と $J 及$ び $\partial \alpha / \partial r$ との関係を求めることがでる。

以下に括いてこれらの関係を椧討する。

$$
J の 一 \text { 定性 }
$$

条件Aをみたす分子 1 及び 2 みマン線が波数の高い あのと低いるのとの二群に分けられる侍は，(1)は波数 の高いラマン線の群，低、群の各々に対するものK分け られる(第 5 報参照)。证って，例穴ば炭化水素に打いて は， 引マン楾心数，波数，波数に対する强度の分布等が分 子構造心相違によって著しく異なっている $1700 \mathrm{~cm}^{-1}$ 以下゙ラマッ線たけについて（（）適用してよい。 


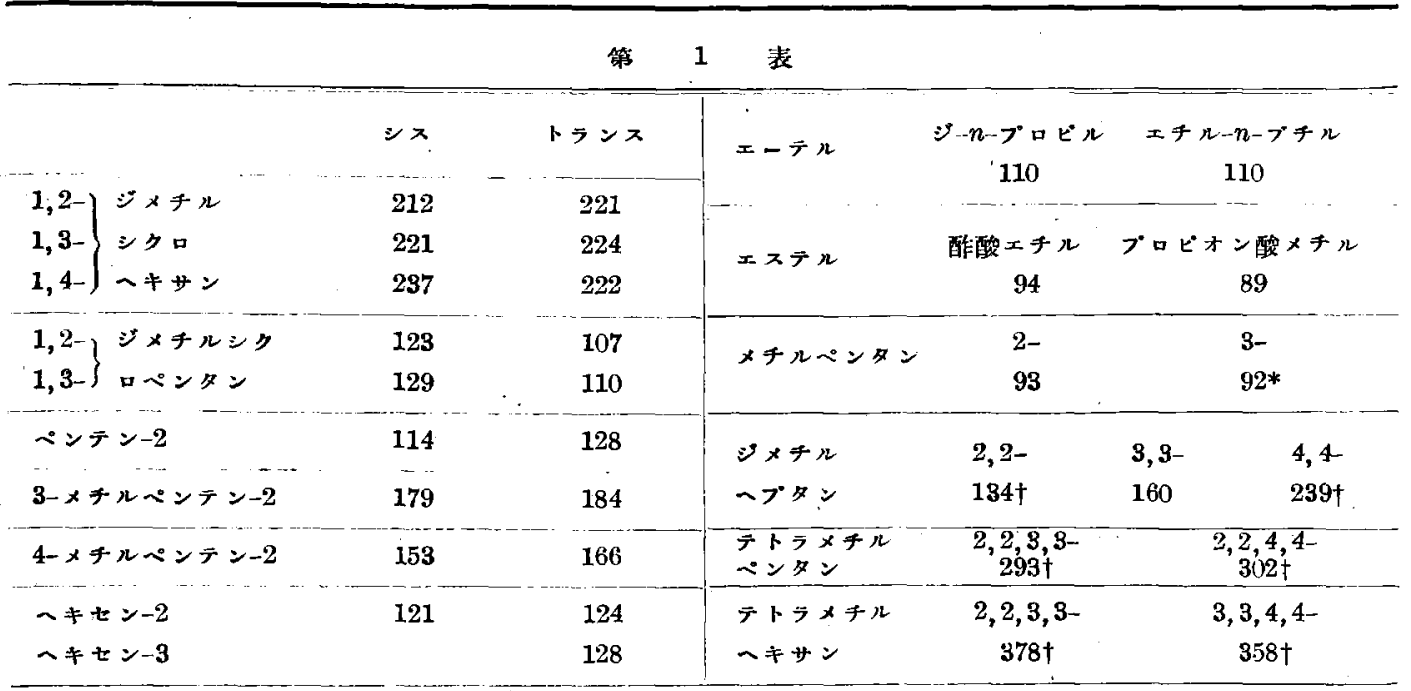

*3ーメチルペンタンの $445 \mathrm{~cm}^{-1}$ のラマン線の強度は, Fenskeの表では 0.56 となっているが, 強屋曲線に よると 0.056 の俱りと判定し得るから，第1表の計第では 0.056 とした.

†印をつけたるのは推定した比重を用いて算出した数值である．推定法は，例えばジメチループタンでは2,2及び 4,4-は 3,3-を比重が等しいとした．この誤差が $J$ の值に攻代す影響は小さい.

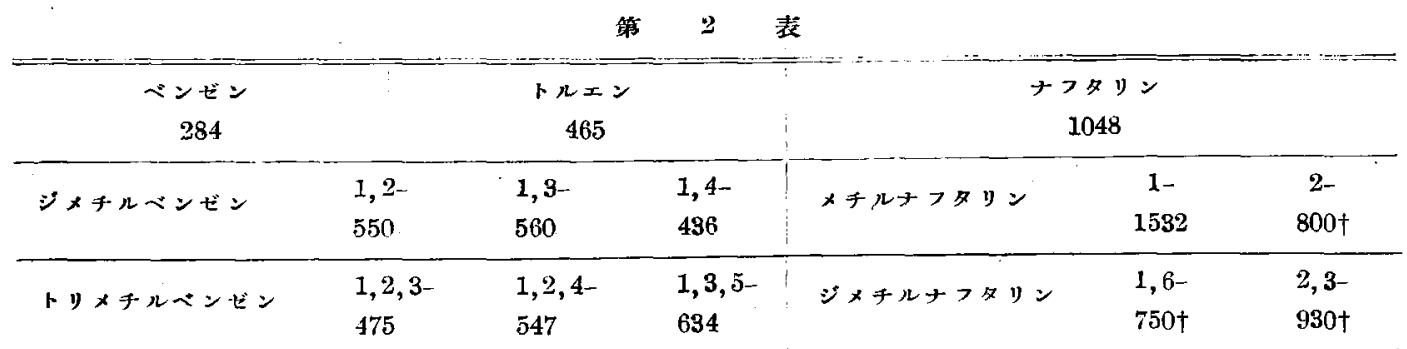

$8000 \mathrm{~cm}^{-1}$ 附近のラマン線は, 分子構造た相違によう波 数に対する强世の分布の相違が小さいから，これらのラ マン線の强度をJから除くことは，分于構浩と $J$ との闇 係を論ずる目的に適合する。

$1800 \mathrm{~cm}^{-1}$ 以下のラマン線の茧度測定は, Fenske 等》 によって多くの化合物について行われているから，以下 の議論にはすべてこれらの强度测定值を用いる。条件 A をみたし，しかも対称性，置換基心位䁂等が異なる分子 の組につ、てJを算昛しな結果は第1表のようになる。 Fenske 等のラマン楾の強度の表ては，f，g線によって 矿起されたるのる0線を起点とする波数が与兄られてい るが,それらの強度は小さいから, 以下の $\Gamma / \omega$ の算出 に扎てe楾を起点とする波数を用いても差支えない。

3) M. R. Fenske, W. G. Brawn, R. V. Wiegand, D. Quiggle, R. H. McOormiek, D. H. Rank, Ind. Eng. Chem. Anal. Ed. 19, 700 (1947); W. G. Bramn, D. F. Spooner, M. R. Fenske, Anal. Chem. 22, 1074 (1950).

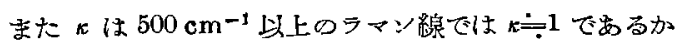
ら，以下の表において $500 \mathrm{~cm}^{-1}$ 以下のラマン線をにけに いて $\kappa$ を計算し, $500 \mathrm{~cm}^{-1}$ 上上のラマン線について

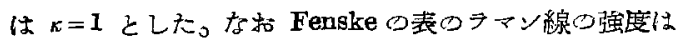
单位容皘当门の虽庭*1であるが, 第1表つJはモ几当り の数値*2でむる。

第1表心脂肪属化合物の备組に扎いては(1)がよくみ たされており，このことはJが分子の刹称性等によらな いことを示している。(1)の成立はまた，各組の分子間

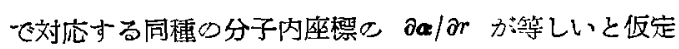
し，浱動及び分皮率变化の非調和性を無視し， (1)のI に液態ての强度测定值を用いてす差支えないことる示し

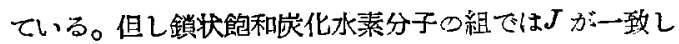

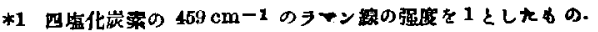

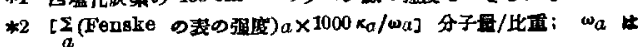
om-1; 比屈it G. Hgloff “Physical congtents of hydrocarbon" New York (1940) によった. 


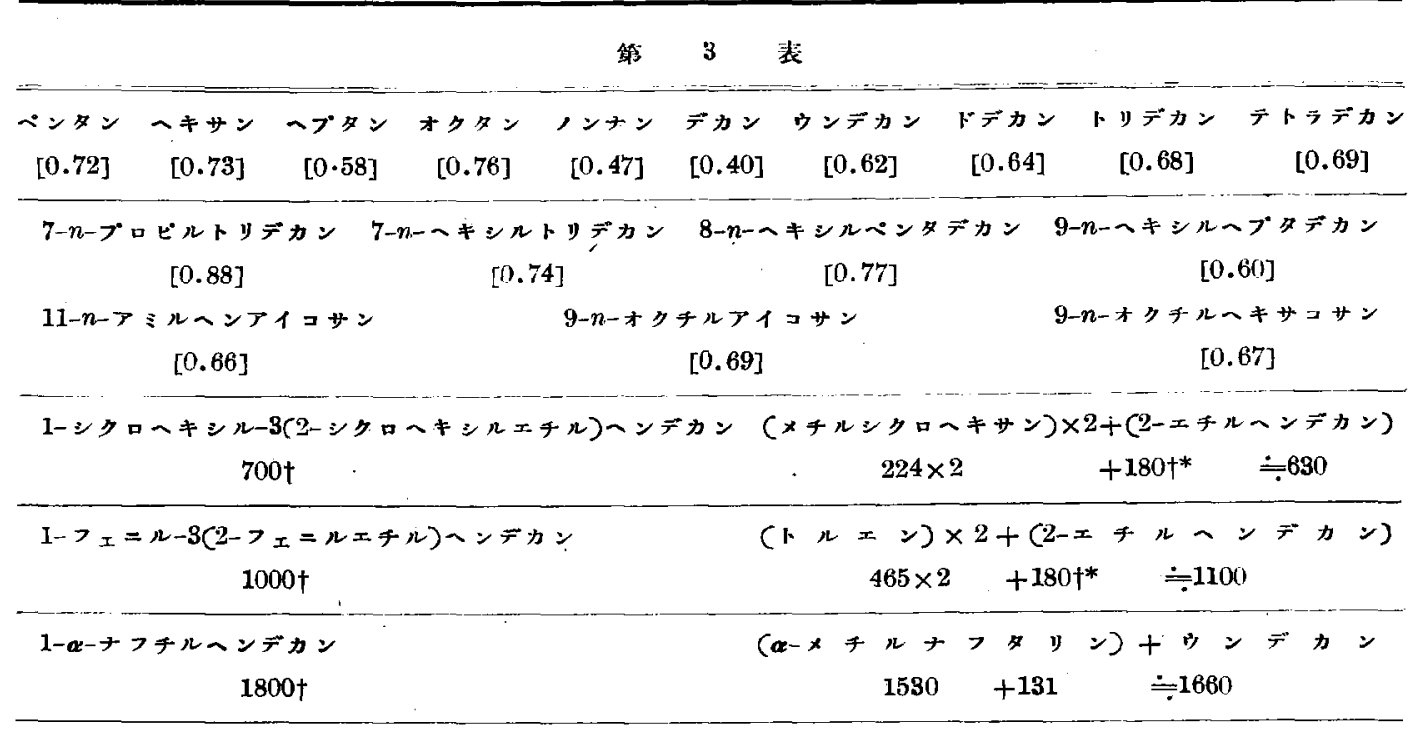

* 表の第 2,3 行の $J^{\prime}$ の平均傾加算讪した。

ない場合があり，表のシメチループタ:は大落しい例 たまる。

ベンゼッ,ナフタリン及びそれらの誘薄体のJは过の 諸点て脂肪属化合物と孯なって和り，この相違はナナタ リン及びその誘筫体で著しい。即ちこれらの芳香属化台 物では第 2 表に示すよ 3 にが著しく大きいこと，メチ 几基川尊人によるJの变化が大きく且つその大きさはそ

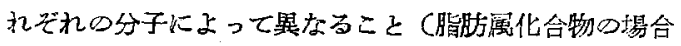
は後の第 4 表参照)，及び位㯰異性体間て $J$ が一定でな いこと等である。これらは，芳香屈分子ては一つの座標

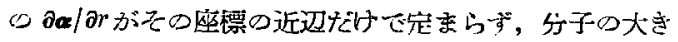
部分或いは分子全体に依度することを示している。

分子量の異なることによる Da/or の焉同をみるため には，分子量の異なる分子間で(2)の成立を確かかれば よい。真鎖飽和炭化水素分子の各々につ、て(2)が战立 するときは，これらの分子のJは忹は分子量に比例す合

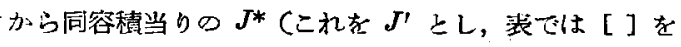
けてJと区別するりは一定となるはずけまる。岸䕀数 がらから 14 までか直鎖飽和炭化水素心 $J^{\prime}$ は第3裁の 第1行の通りでるって，これらの $J^{\prime}$ ひ一致はよくない、

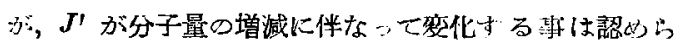

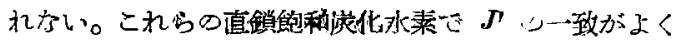
宁いのはこれらの分子には $1700 \mathrm{~cm}^{-1}$ 以下に强い マッ線がなく，背景を引き去るときに学入される强庭測

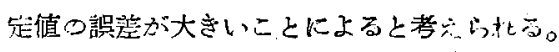

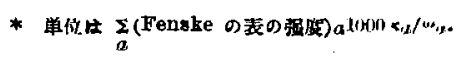

後䬣にのベるよ 5 に炭素銷の分枝があると J'は大き くなるのであるが，表の第 $2 ， 3$ 行にぬげた分子のよ5 に分子量が非常に大きく分枝が一つである壦合には，分

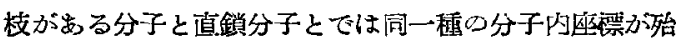

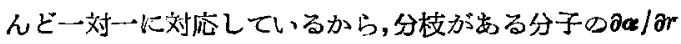
が面鎖分子の Da/ar と同一ならば(2)によりJ゙は阿種 分子で同一となる。第 2,3 行の㞸菜数 32 まての銷状 飽和宸化水素分子について算出した $J$ が，第1行とほ

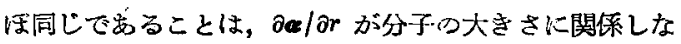
いことを示している。

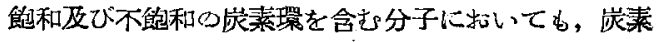
罢の妍くの構造が比較する分子間で变らなければ, 表の 第 4，5，6行のよ弓にJの加成性が成立するから，乙 れらの分子の組に颃いて対応する座䅺の 2a/ar は变ら ないと考穴られる。

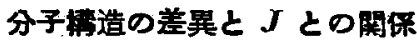

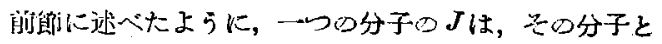
D間に条件A孛みたす分子に共通であるから，条件 $\mathrm{A}$ 欢たさない分子間一一例完ば分柀心異なる分子間——て

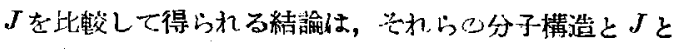
の関保を一般的に岁らわすことになる。

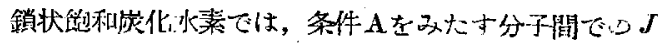
》一致はるくないが，分枝心状態とJと心関係を定性的

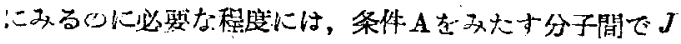

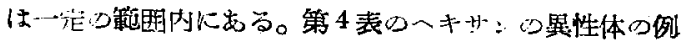

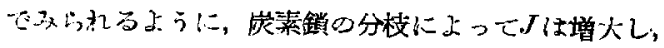




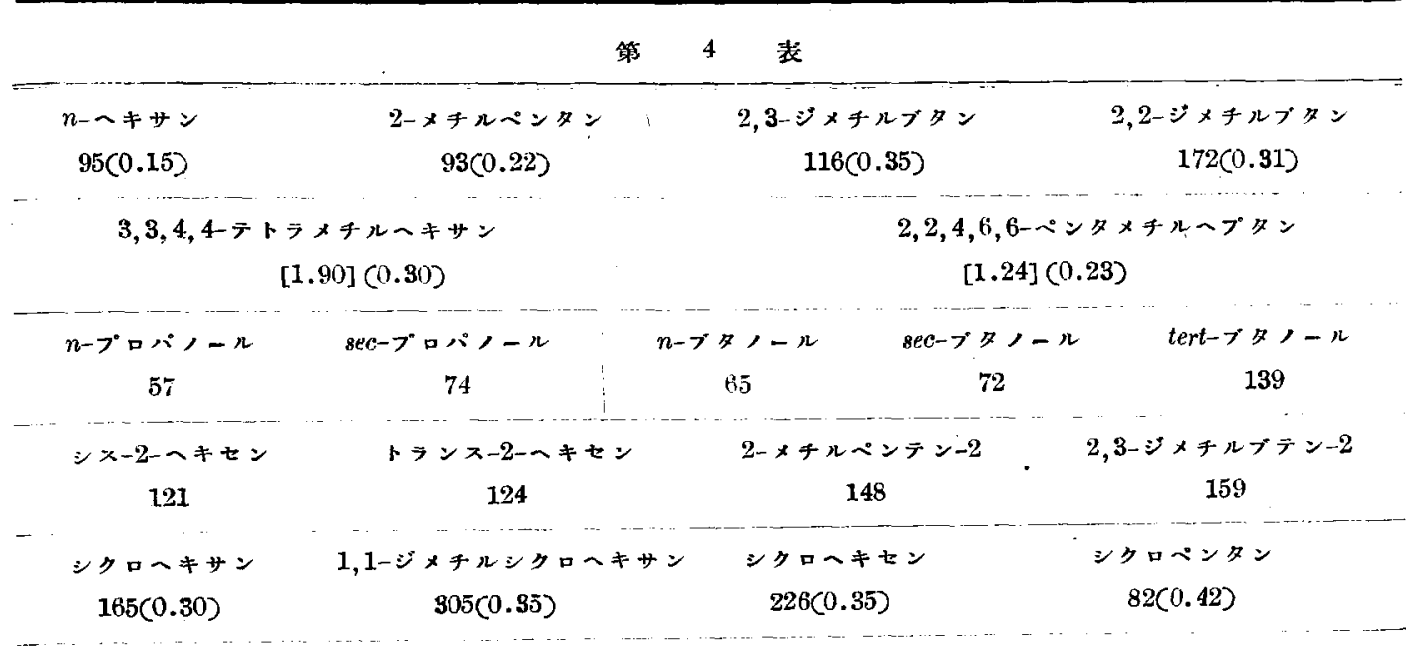

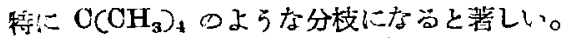

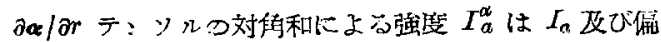
光解消度の測定值から求められる。Fenske の表では偏

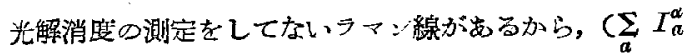
$\left.\times 1000 \kappa_{a} / \omega_{a}\right) / J^{\prime}=R$ は不正確こむるが, 分枝によって $R$ (表の(つをつけた数檤)が增加子るのが認められる。 岸秦鎖の分枝により $\mathrm{O}-\mathrm{C}-\mathrm{C}$ 及び $\mathrm{H}-\mathrm{C}-\mathrm{H}$ 变传

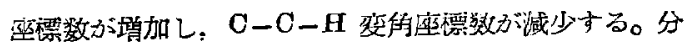

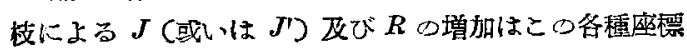
妆力变化によるであろろが，メ千几基或いはメテレン基

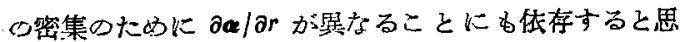
かれる。座標数が变らずにメチ几基，メチレン基放滵集

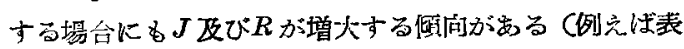

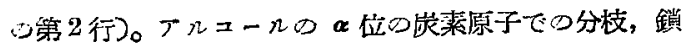

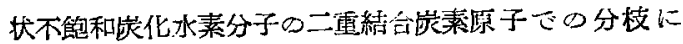

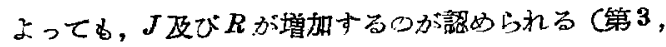
4 行)。

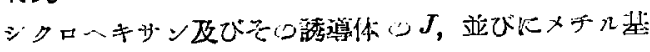

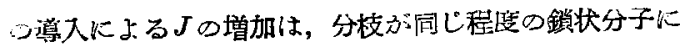

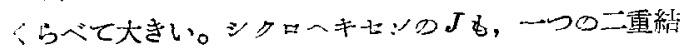
公を持つ鎖状扊化水素上り大きいから：シクロへキサシ

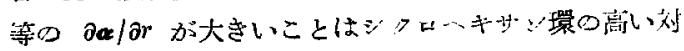
称性によるのではない。他方，炭装環に雪子があり，平

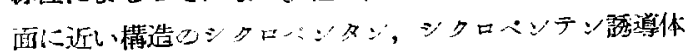

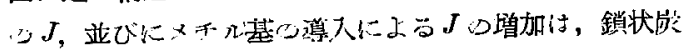

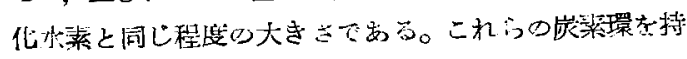
つ分子ては $R$ が大きい(第5行参塬)。

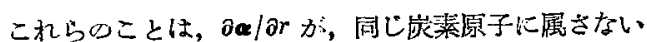
座標間の相互作用に依存することを示すが，相互作用の

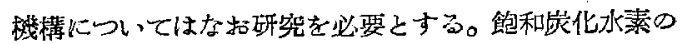
鎖状分子と環状分子とでは $\boldsymbol{F}$ ，文文項が留なるでする ちが，この善異が，Jに上記のような著しい相違を与充 る程に大きいとは考允難い。

\section{総括}

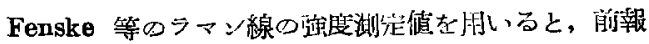
で導旪したテマン線の強度の和の式， $J_{1} \equiv \sum_{a} I_{1 a} \kappa_{1 a} / \omega_{1 a}$

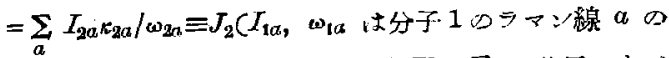
強度及び波数， $\kappa_{a}=1-\exp \left(h \omega_{a} / k T\right) ， \sum_{a}$ は分子のす心

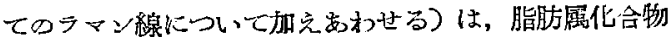
においてはよくみたされており，このことはJが分子の 対称性遙によらないことを示している上記の式が成立 することはまた，同属列分子間だ $\partial \alpha / \partial r$ ( $\alpha$ は分極等， $r$ は分子内座標つが同じであると仮定し，振動及び分極

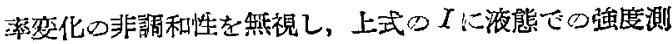
定値を用いても差支觉ないことを示している。しかしな

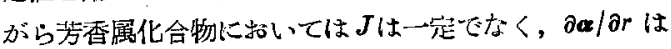
同一てない。また炭㨞鎖の分枝或い、宸素環が存在する と $J$ ，及びJの等方性部分の慧台が大きくなる。

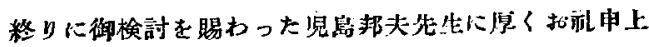

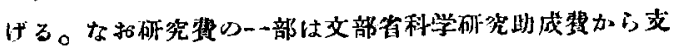
出した。附部して感謝する。

(昭和 28 年 4 月，日本化学会第的作会满演) 